\title{
Spiritual Interventions in Juvenile Delinquency
}

\author{
Umut Kermen ${ }^{1}$ (1) \\ Marmara University
}

\begin{abstract}
This study is a review on spiritual and religious oriented interventions for juvenile delinquents. The article is composed of five parts, namely: (i) juvenile delinquency, (ii) the relationship between crime and spirituality, (iii) spiritual interventions for juvenile delinquency, (iv) spiritual interventions in prison for delinquent children, and (v) spiritual interventions in schools for delinquent children and their family. In the first part, the definition and scope of juvenile delinquency and the factors for committing a crime are given. In the second part, theories of spiritual psychology concerning juvenile delinquency are expressed. Faith-based intervention approaches, group psychological consultation approaches, and the spiritual interventions and counseling proficiencies of positive psychology's spiritual intervention and counseling proficiencies are discussed in the third part. In last part, space has been given to in-school interventions and prevention approaches for families.
\end{abstract}

\section{Keywords}

Juvenile delinquency $\bullet$ Spiritual interventions $\bullet$ Faith-based programs $\bullet$ School-based interventions $\bullet$ Family

\section{Suça Sürüklenen Çocuklarda Manevi Müdahaleler}

\section{$\ddot{\mathrm{O} z}$}

Bu çalışma suça sürüklenen çocuklarda maneviyat ve manevi yönelimli müdahalelere ilişkin bir derlemedir. Makale beș bölümden oluşmaktadır. Bu bölümler çocuk ve ergen suçluluğu, suç ve maneviyat ilişkisi, suça sürüklenen çocuklarda manevi müdahaleler, okullarda suça sürüklenen çocuklara ve ailelere yönelik müdahale ve önleme yaklaşımları, ceza ve infaz kurumlarında suça sürüklenen çocuklar için manevi temelli müdahalelerdir. İlk bölümde çocuk suçluluğunun tanımı, kapsamı, suça sürükleyen etkenlere yer verilmiştir. İkinci bölümde, suçu açıklayan manevi psikolojinin teorilerine değinilmiştir. Üçüncü bölümde bu çocuklar için geliştirilen inanç temelli müdahale yaklaşımları, grupla psikolojik danışma yaklaşımları, pozitif psikolojinin manevi müdahalesi, danışmanlık yeterlilikleri anlatılmıștır. Son bölümde ise suça sürüklenmiş çocuğa sahip ailelere ve okulda çocuklar için geliştirilmiş manevi müdahalelere yer verilmiştir.

\section{Anahtar Kelimeler}

Suça sürüklenen çocuklar • Manevi müdahaleler • İnanç temelli programlar • Okul temelli müdahaleler • Aile

\footnotetext{
1 Correspondence to: Umut Kermen (PhD Student), Institute of Educational Sciences, Guidance and Psychological Counseling, Marmara University, Istanbul 34722 Turkey. Email: umutkermen@gmail.com
}

Citation: Kermen, U. (2018). Spiritual interventions in juvenile delinquency. Spiritual Psychology and Counseling, 3, 61-84. http://dx.doi.org/10.12738/spc.2018.1.0038 


\section{Juvenile Delinquency}

Although juvenile delinquency can be defined as criminal offenses committed by adolescents and children, this definition can sometimes be inadequate. In recent years, some actions in which children and adolescents get involved are considered unwanted and delinquent that is not normally considered to be criminal offenses for adults. Examples include running away from home, truancy, and lawlessness. Although, is the maximum age for the defense of infancy is 18 , crime is also observed at a younger age. Individuals under the age of 18 are considered children and are judged differently based on their age. Three separate age groups are established for juvenile delinquency in the Turkish Penal Code. Since criminal liability begins at age 12, children between the ages of 0 and 12 are not punished. Children between the ages of 12 and 15 may be given penalties at a reduced rate based on how they perceive the outcome of their behavior, their ability to control their actions, and their understanding of the legal content of the crime. Similarly, children between the ages of 15 and 18 may also be given a punishment at a reduced rate. In other words, a juvenile delinquent is neither held to the same level of criminal responsibility nor is he charged to the same extent as adults for the same crime because he is a child (Bülbül \& Doğan, 2016). Crimes committed by children under the age of seven are not considered a crime because the perception of crime does not develop in children until the age of seven. The reason that individuals under this seven are not regarded to have any criminal responsibility is the underdevelopment of their reasoning system and their lack of comprehension of the concept crime. For individuals under the age of seven, rehabilitation and home supervision programs are mandated instead of punishment (Shoemaker, 2008).

After reviewing the aspect of criminal responsibility in criminal activity, it is necessary investigate judicial discretion in Turkey. Discretions made for juvenile offenders are delineated in the Child Protection Law. According to Turkish law supervised release, counseling, education, care, and health care decisions can be given for delinquent children. These measures are defined as supportive and protective. If education is ordered, the child is either to attend an educational institution daily, to be enrolled in a vocational acquisition course, or to be placed in a workplace within the public or private sector. If care is mandated, is the child is to be provided with some form of private or preventive family or guardian services, provided that the person otherwise responsible for the care of the child is unable to perform his duties for any reason. Healthcare may be ordered for a child so that he may receive temporary or permanent medical care and rehabilitation in order to protect the child's physical and mental health or to treat children or adolescents who use addictive substances. Counseling is mandated to guide the child in solving his educational and developmental problems and to guide those responsible for the child in how to raise children. As for supervised release, its aim is to ensure that the child has an appropriate education, social, and 
familial environment. Guidance can be offered on their rights and how to exercise their rights. The implementation and effects of decisions are observed. Information about the child's family and environment, his living conditions, and how he spends his free time is collected and presented to the court every three months (Child Protection Law, 2005).

Regarding the types of crimes committed by children requiring the above-mentioned measures to be taken include intentional killing, wounding, sexual abuse, physical violence, theft, promoting prostitution, extortion, setting a fire, and drug use and selling. Of all crimes committed by juveniles, $25 \%$ are provoked by others, $45 \%$ are planned with a few people including the juvenile, s and $30 \%$ are committed solely by themselves (Köknel, 2017).

Risk factors pertaining to these crimes are divided into five groups, namely: (i) individual, (ii) family-related causes, (iii) the effect of peer groups, (iv) school, and (v) the place of residence. Individual causes include the existence of hyperactivity and attention deficit disorder, high risk-taking behavior, lack of empathy, impulsivity, difficulty in pleasure postponement, low intelligence level, lack of self-control behaviors, and having a hard temperament. Family-related causes include a low socio-economic level, living with a large family, coming from a divorced family, inconsistency and lack of control in child-rearing, parental indifference, family abuse, exploitation within the family, violence against the child, being an individual involved in crime between family members, conflict between parents, and the persistence of anti-social behavior among generations. School-related causes include low academic achievement, lack of commitment to school, low motivation to school, disbelief in one's teacher, truancy, and being a victim of bullying in school. Regarding the effects of peer groups, having an anti-social group of friends and having a delinquent friend are the most important indicators. The effects of the child's community are cultural and include socio-economic level, social irregularity in the community, community solidarity, and the desires and abilities of those living in the community (Topçuoğlu, 2004). In addition, recently emerging social variables underlying the phenomenon of crime have been examined. These include the weakening of social and familial ties, immigration, mobility within the country, the weakening of a group membership, the weakening of values, and difficulties in transferring values to others (Coşar, 2005).

It is necessary to discuss individualization in juvenile delinquency in its own paragraph. The concept of coexistence brings together the concept of being us. To be human means to be part of a social group and a religious group and to be supported by these groups. Breaking away from traditional values and ties renders the person on his own in changing community. The break from these values appears in four ways, namely: (i) the disappearance and ineffectiveness of the rules that determine acceptable human behavior (ii) individuals overtaking the community as the creators of social events, (iii) 
increase in self-centeredness, and (iv) the breakdown of religious, family, and social communities and the weakening of traditional values (Coşar, 2005).

Another issue that seems to constitute a problem in Turkey and that drives children to crime is being abandoned to the streets and employed. The concept of street children, a general concept for such children, is used. Such children are deprived of any protection and adult support. UNICEF classifies these children according to the state of their family ties. Children in the first group are considered "children on the street" and include those children with family ties who work in the street during the daytime and who return home in the evening. Those children whose family ties are inadequate, or irregular are categorized as potential children of the street. The term "children of the street" is used for those children having is no adult support or protection and who live and sleep in the street. Children in the last group who have the greatest potential to commit crime are those who are thrown out of or who run away from home. Furthermore, these children might not have a family (Ennew, 2003). Children in the risk group might find themselves exposed to crime, develop a criminal tendency, or be driven to commit crimes themselves. The crimes that these children may commit include violence, neglect, abuse, use of addictive substances due to neglect, being forced into prostitution, begging, wandering the streets, and creating street gangs composed of members over 15 years old who are aggressive and who exhibit violent behavior (Güngör, 2008).

In summary, 18 is the upper age limit for juvenile delinquency. In the Turkish Criminal Code, three age groups (i.e., 0-12, 12-15, and 15-18) are listed in determining sentences for offenses committed by children. No punishment is given for those children under the age 12. The concept of crime has not developed in individuals under the age of seven. In addition to individual, family, peer groups, school, and community causes, being on the street and working are variables that constitute risk factors in juvenile delinquency. The sociological change of society as a result of the concept of "being able to be us" is another influence that can determine criminal behavior.

\section{Relationship between Crime and Spirituality}

In providing the definition of spirituality at this point, it is important to understand the relationship between these two concepts. Spirituality is to try to be connected with and be close with the sacred (Waaijman, 2007). Although there is no need for any religious belief in spirituality, people mostly live their spirituality through their religious beliefs (Pargament \& Saunders, 2007). As such, although spirituality and religion seem to be separate entities, they also overlap (Summermatter \& Kaya, 2017). The relation between crime and spirituality has been discussed in forensic psychology (Bartol \& Bartol, 2014) and social psychology (Yoshikawa, 1995) for many years. These studies focus on the correlation between crime and spirituality, the 
theories for explaining and describing these variables, and the use of religion, belief, and spirituality to prevent and reduce criminal behavior (Johnsong \& Jang, 2011).

According to the literature, religious adolescents commit fewer crimes than their non-religious peers (Allen \& Lo, 2010; Chui, Cheng \& Wong, 2013). Fear of God's retribution and the idea that committing crime contradicts spirituality are two explanations for this behavior. The conflicting situation brought on by this consciousness leads to feelings of shame when a crime is committed. Attending a religious group, the focuses on issues of belief can also prevent criminal behavior because such groups do not approve of criminal behavior. Being in a religious group builds loyalty, a commitment to certain religious and secular behaviors, participation in rituals, and faith-based partnerships. Such social and religious oversight is effective in reducing criminal behavior. It is observed that a family's being religious and having the desire to raise their children on religious values are factors that prevent criminal behavior in children. Adolescents who have friends who act as models to them and with whom they can learn religious and spiritual behaviors are also less likely to engage in criminal activities. In addition, adolescents who use religion and spirituality as coping skills tend to interpret criminal behavior and difficulties in life with negative emotions. By thinking that God will not like the crime, they conclude that crime is also negative (Johnsong \& Jang, 2011).

When considering the relationship between religion and juvenile delinquency, there are two main religious methods that protect children from committing crime and that prevent them from repeating a crime previously committed. These methods are to maintain continued attendance to a religious institution, place of worship, etc. and to keep one's religious life at the fore, to organize one's life according to religion, and to consider religion in behavior choices (Salas-Wright, Vaughn, \& Maynard, 2014). A longitudinal study of the situation of continued attendance to a religious organization revealed that children who had been included in the religious organization beginning at the age of 15 committed fewer crimes by the age of 18 (Herrenkohl et al., 2003). Likewise, children attending a religious organization are less likely to have problems with their teachers than those who do not (Smith \& Faris, 2002). In addition, as delinquent children continue to engage in a religious organization, their lives and behavior are regulated according to their religion and are less likely to fight with their peers (Salas-Wright, Vaughn, Hodge, \& Perron, 2012). Making religion the forefront of one's life is seen as the most protective factor against violent behavior in delinquent children. The child who chooses to regulate his behaviors according to religion has fewer fights and does not show weapon-carrying behavior (Powell, 1997).

In addition to these religious and spiritual resources, religious coping behaviors are also important sources reducing and preventing unwanted criminal behavior. Children 
who have spiritual-religious coping skills are less likely to engage in criminal behavior than their peers. One of the skills used by children with who have developed religious coping behaviors is forgiveness. Forgiveness is a supported quality in all world religions. The act of forgiving diminishes one's desire for revenge and does not reveal the self-imposed crime. Children who make forgiveness a skill also better understand people who are discriminated against, abused, and victims of any event. For this reason, forgiveness is a functional spiritual coping skill that prevents crime (Agnew, 2006).

Children without religious coping skills are more insensitive to religious-spiritual stimuli. They have a tendency to exhibit risky behavior due to their religious/spiritual insensitivity and tend to choose social environments that engage in criminal behavior. These children are diffident and are reluctant to participate in religious activities, finding such participation boring and devoid of satisfaction (Cochran, Wood, \& Arnelklev, 1994).

After looking at the relationship between juvenile delinquency and spirituality in terms of individual coping skills, an important area requiring investigation is the social environment and the family' stance regarding the relationship between crime and spirituality. What is meant by stance here is whether there is a control mechanism over the child, either secular or religious. Religious or secular variables that regulate the child can be defined as participation in family activities, restriction of friendships not approved by parents, parental deterrence, family rules, and quality of relationships in the home. The existence of these concepts in the family, with or without religious rules, provides an assessment of the concept of spirituality and criminal behavior. Families that adopt these concepts actively prevent and protect their children from engaging in criminal behavior (Johnstone, 1997).

Another phenomenon that arises when discussing crime and spirituality in terms of social environment consists of the changes and transformations that the child has experienced. The results of the changes and transformations are analyzed from the social point of view and are linked to crime and spirituality. A child's reaching puberty, progressing into high school, moving from one's place of residence, and others' expectations about studying in university constitute changes and transformations. Among the results of such changes and transformations are questioning one's own religious values, encountering crime and places where crime is committed, frequenting places of worship less often. These changes and transformations can also cause children to engage in criminal behavior (Elder, 1998).

Looking at the relationship between crime and spirituality from a social point of view, the direct and indirect effects of religion on crime are difficulties transmitting religious and spiritual values from one generation to another, delaying this transfer, and paying no attention to the social relations with adults who will teach religious values. The difficulty, delay, and disregard in transferring religious values are due 
to inadequate religious knowledge. Religiosity and religious identity of the family influence the child's religious identity, religious attitudes, and participation in places of worship (Regnerus, 2003). Changes and transformations experienced during childhood lead the child not only to adopt a set of religious beliefs similar to that of his family but $t$ question criminal behavior. Children whose religious beliefs differ from those of their family are more likely to engage in criminal behavior than their peers whose religious beliefs are similar to those of their family. Similarly, the degree of value given to religion has an important relationship with juvenile delinquency. If the child deems religion to be less valuable than his parents, the likelihood of his committing a crime is even greater. In terms of crime, it is more dangerous that a child not consider religion important than for him to believe in a different religion from his family (Pearce \& Haynie, 2001).

\section{Spiritual Interventions for Delinquent Children}

Well-being is the first concept used in the treatment of delinquent children. In psychological counseling with these children, efforts are being made to improve the well-being. The four dimensions of well-being are physical, mental, social, and spiritual health. The aim of spiritual health work is to increase the well-being of delinquent children. In the spiritual health dimension of the intervention, attempts are made to bring balance to delinquent children's lives, to improve wholeness, and to instill hope energy, peace, and tranquility (Pulla, 2014).

Social support and spirituality can also be used to increase delinquent children's well-being and as interventions into such children's social problems, which include choosing bad friends, having weak social connections, and having difficulty communicating (Salas-Wright, Olate, \& Vaughn, 2013). Since social problems and having trouble adapting make adolescents prone to crime, it is necessary to examine social support mechanisms in psychological counseling. Supportive psychological counseling with a social aspect to it is useful in protecting the child's mental health and in using spirituality effectively. Social support is a type of intervention that reduces stress in the child, helps him develop spiritually, and gives purpose to life (Cohen, 2004). When social support is used as an intervention method together with spirituality, it helps the child to develop his own decision-making behaviors and to understand his own internal processes (Mirowsky \& Ross, 2003).

Another therapeutic method being studied with juvenile offenders is the teaching of life skills. These studies may be conducted in the form of psycho-education and psychological counseling. Life-skills training involves bestowing knowledge on the child, changing behaviors, and helping him acquire skills. The fundamental principle in psycho-education and psychological counseling given to delinquent children with the aim of teaching life skills is that the child should be able to reconnect with his 
environment. Reconnecting is carried out through exercising self-control. The topics of counseling sessions can be gender roles, discussion of substance use, aspects of family life and crime, media influences on behavior, risk factors in the environment, sexual behavior, decision-making behaviors, and social self-efficacy. Another skill studied in counseling sessions where life skills are taught is spiritual coping skills, and it is aimed that child become empowered through spiritual coping skills. Efforts are being made to transfer positive life experiences into spiritual empowerment and to develop a healthier life (Pargament, 2002). Spiritual coping skills are sought to be imparted during the activities. Children experience an increasing in quality of life and decrease in recidivism through the acquisition of spiritual coping skills (Singh \& Bhadra, 2014). Positive psychology suggests a group counseling approach to provide spiritual coping skills for delinquent children. Drawing and describing emotions are used in sessions to help delinquent children acquire spiritual life skills. In addition to this, the aim of psychological counseling is to help such children develop an understanding of justice, to aid them in seeing love and in gaining the ability to express love, to assist them in building a connection with the deeper spiritual world by instilling in them the ability to choose, and to teach them how to display correct behaviors (Wahl, Cotton, \& Monore, 2008). Described so far, the approach used to help such children develop spiritual life skills is shown in Table 1 (Singh \& Bhadra, 2017):

Table 1

Spiritual Life Skills Development Approach

\begin{tabular}{|c|c|c|}
\hline $\begin{array}{c}\text { Life Skill Activity Sought to } \\
\text { be Developed }\end{array}$ & Aim of Session & Spiritual Side of Session \\
\hline $\begin{array}{c}\text { Meditation and relaxation } \\
\text { exercises }\end{array}$ & $\begin{array}{l}\text { To facilitate relationship } \\
\text { building. }\end{array}$ & Meditation is the first step. \\
\hline Imagination and storytelling & To attract children's attention. & $\begin{array}{l}\text { Children narrate their dreams anecdotally, } \\
\text { rewrite stories, and connect with their } \\
\text { inner-self. }\end{array}$ \\
\hline Question and answer sessions & $\begin{array}{l}\text { To raise children's awareness } \\
\text { through discussion. }\end{array}$ & $\begin{array}{c}\text { An increase in children's self-esteem } \\
\text { through free discussion. }\end{array}$ \\
\hline $\begin{array}{l}\text { Future work sessions } \\
\text { considering past experience }\end{array}$ & $\begin{array}{l}\text { To looks at the past with a } \\
\text { realistic gaze and to question } \\
\text { one's wrong decisions. }\end{array}$ & $\begin{array}{l}\text { The development of spiritual skills } \\
\text { like hope and self-forgiveness and of } \\
\text { interpersonal skills such as forgiveness. }\end{array}$ \\
\hline
\end{tabular}

In these sessions, counselors can enter into the thought structures, beliefs, and religious aspects of the child. The main aim of the sessions is to find meaning in the child's life and to strengthen their connection with their own inner spiritual world. One of the roles of psychological counselors in life skills education is to consider that children's spirituality and the cultural and religious beliefs that they advocate will shape the counseling session. The cultural and religious background coupled with the counselor's support will lead to the strengthening of ties with the transcendent and with the child's own inner spirituality. The counselor's honesty toward the client, patience, and tolerance make it easier to progress in psychological counseling. 
Progress is achieved when the child produces his own effective spiritually-based solutions (Singh \& Bhadra, 2017). In psychological counseling, the role and skill of the counselor in asking questions are also considered important to understand the child's spiritual world. The ability to ask questions is divided according to the possible themes and the spiritual experiences that may arise from the processing of these themes during consultation. Possible thematically-based questions to be asked during consultation are shown in Table 2 (Miller, 1999):

Table 2

Spiritual Questioning Skills in Psychological Counseling

\begin{tabular}{|c|c|c|}
\hline Theme & Spiritual Experience & Possible Open-ended Questions \\
\hline \multirow{4}{*}{$\begin{array}{l}\text { Awareness of } \\
\text { the Sacred }\end{array}$} & Awe & What are your thoughts about the Sacred? \\
\hline & Deep Respect & What inspires in you admiration and awe? \\
\hline & Happiness & Who and what can you make sacrifices for? \\
\hline & Joy & When did you feel deep joy in your life? \\
\hline \multirow{4}{*}{ Destiny } & Helpfulness & Can you describe the image of God? \\
\hline & Trust & What do you think about the afterlife? \\
\hline & Hope & What and whom do you trust? \\
\hline & & What gives you hope? \\
\hline \multirow{4}{*}{ Faith } & Security & What do your connection mostly to in your life? \\
\hline & Safety & How safe is your life? \\
\hline & Courage & Who and what do you believe in? \\
\hline & Connectedness & What worries you? \\
\hline \multirow{4}{*}{ Gratitude } & Smartness & What are you most grateful for? \\
\hline & Forgiveness & When did you feel that your life was truly blessed? \\
\hline & Contentment & When was it difficult for you to forgive someone? \\
\hline & Blessing & When were you forgiven by someone? How did that happen? \\
\hline \multirow{4}{*}{ Repentance } & Remorse & What do you think you should do, to be a better person? \\
\hline & Regret & What do you regret in your life? \\
\hline & Feeling bad about oneself & When did you feel guilty and full of shame? \\
\hline & & $\begin{array}{l}\text { When did you want to change your life? What have you done } \\
\text { to change it? }\end{array}$ \\
\hline \multirow{4}{*}{ Connectedness } & Feeling of belonging & In which situations do you feel connected to other people? \\
\hline & To be loved & Where do you feel at home? Where do you belong? \\
\hline & The Feeling of togetherness & Who are you important for? \\
\hline & Compassion & Who do you give importance to? \\
\hline \multirow{3}{*}{ Invitation } & Meaning & What is your aim in life? \\
\hline & Purpose & How do you spend your time? \\
\hline & Message & How do you want to shape your life over the years? \\
\hline
\end{tabular}

Another intervention approach consists of belief-based interventions seeking to treat delinquent children, to help them readapt to society, to prevent recidivism, and to conduct preventive work. These are nonprofit, social welfare organizations based on Christian theology and are usually supported by the state. Although this form of intervention based on Christianity, the techniques used by them can also work in mosques and synagogues and by temple officials and clergies of other religions. These institutions provide religious counseling, guidance, mentoring, and pastoral care 
services. Some institutions also provide secular spiritual counseling services (Neff, Shorkey, \& Windsor, 2006). Four types of faith-based social welfare organizations have been established: (i) secular counseling services that make no reference to any divinity or to the divine, (ii) organizations affiliated with a religious group but that do not use religious techniques or content in their interventions and services,(iii) organizations that use religious content as a whole and that do not use non-religious techniques, and (iv) organizations providing holistic, and spiritual/religious aid that use religious and non-religious sources. The main spiritual working areas of the organizations involved in this definition are children who use drugs, those who are delinquent, and those who want to improve their social relations (Sider \& Unruh, 1999).

When looking at the composition of faith-based intervention agencies, it is seen that they are composed of anywhere between two to several hundreds of staff and volunteer workers. The number of consultants who actively go to these institutions varies from 15 to 130 depending on the number of suitable facilities and employees. The number of children served annually can range from 150 to 2,700. The reason why the number of people served is so high is that individuals who use narcotic substances and alcohol are included in these services. Services given at institutions are provided free of charge. The duration of social, individual, counseling, and psychological health care given varies from one month to one year depending on each specific program. Those serving in such institutions consist of counselors at the doctoral level, psychologists, volunteers, pastoral counselors, and religious group members affiliated with the institution (Neff, Shorkey, \& Windsor, 2006).

Belief-based interventions are planned in eight dimensions. The first dimension consists of a spiritual and religious vision and mission statement. The second dimension consists of the results to be attained from the program, namely spiritual development and religious transformation. The program's identity constitutes the third dimension. One of the core features of the program is that it is based on a certain faith system. Both religious and secular activities are also given place in the program and comprise the fourth and fifth dimensions, respectively. The religious thoughts and background of the client constitute the sixth dimension of the program. The religious backgrounds of the program's staff members and volunteers constitute the seventh dimension and the client's relation to religious communities is the eighth and final dimension of faith-based intervention programs (U.S. Department of Justice, 2011).

The planned services provided by these organizations cover a large area, namely: (i) mental health and counseling services, (ii) guidance services, (iii) family counseling services for parents with delinquent children, (iv) education services, (v) education/occupation preparation, (vi) health/medical services, (vii) accommodation, (viii) relief for financial difficulties and lack of food and clothing, (ix) spiritual 
development studies, (x) guidance and psychological assistance in substance use, and (xi) individual/group/family counseling (U.S. Department of Justice, 2011).

Faith-based intervention approaches are similar to educational programs and can be divided into three parts, i.e., input, intervention, and output. This three-part model is also a treatment plan. Input includes the availability of client, practitioner, and program resources. Intervention includes behavioral interventions, social skills/ support, cognitive interventions, and therapeutic services. During the intervention process, the client's participation in the program, his therapeutic relationship, psychosocial change, and behavioral change are tracked. Post-treatment outputs are two-fold: (i) the prevention of substance use and criminal behavior and (ii) the increased of social supports (Simpson, 2004).

It is also necessary to examine the activities of belief-based interventions that are presented as psychological help. A psychological counseling session may include discussing the client's involvement in religious groups and religious rituals, discussion of participation in a community, church, synagogue, or religious group, discussion of the client's spiritual or non-spiritual needs, individual prayer, group prayer, study of religious texts and materials, building new social relationships, assisting the client in his spiritual development, and promotion administrators, professionals, and psychological counselors to establish a relationship with the client. The above spiritual- and secular-based activities indicate that delinquent children mostly need to acquire social skills, to acquire new or complete existing social relations, and to be supported by others. As a result of the programs, the expected outputs of delinquent children were determined. For these children, program outputs include strengthening their spirituality, reduced criminal behavior, a reduction in substance and alcohol use, an increase in pro-social behaviors, strengthening family ties, strengthening life skills, finding a fixed place of residence, continued education, and gaining job competency (U.S. Department of Justice, 2011).

Another faith-based intervention study was conducted with children with a high risk of delinquency. The program in this study contained four aspects, namely: (i) children who are delinquent or who are at risk of being delinquent, (ii) the guidance, education, and job skill interventions to be provided to these children, (iii) religious institutions, and (iv)I the police and lawyers. The total number of children participating in 13 programs was 494. Activities were carried out after school. The criteria for defining risk in the program were having received disciplinary punishment at school, having low grades, maintaining low grades for a long time, causing trouble in school, fighting, having a history of breaking rules, and frequent truancy. A child meeting any of these criteria was able to participate in the program regardless of his religious beliefs. A number of institutions, mainly judicial in nature (e.g., courts and the police), followed 
respectively by schools, social welfare organizations, families, and relatives, referred delinquent children to participate in the program. Participants can also come in on their own or through volition or through church referral. Throughout the program, atrisk children are encouraged to spend more time with their family and to participate in extracurricular activities (Branch, 2002).

Looking at the program's interventions, mentoring finds itself at the fore. Just as the group has a mentor, so does the child have if needed. Mentoring services are of a spiritual and religious nature. In educational interventions, the child receives help with his school lessons and homework. Children who have dropped out of school are provided educational support so that they may receive a General Equivalency Diploma (GED) Job and vocational counseling services are provided so that these children may become business owners, set goals, plan their career, acquire job finding skills. In the intervention aiming to impart life skills, children learn communication skills, financial management, proper hygiene, and sexual education. The cultural services provided include participation in theater, museum tours, and sports activities. One of the spiritual and religious practices in group and individual mentoring sessions is praying. According to the wishes of Christian and Muslim participants in the group, the praying styles of these religions can be performed together. In another discussion group, the Bible and the Qur'an are read and discussed among those participating in the group. World religions are taught by mentors to children at risk of delinquency. In such sessions, a mentor might bring any number of subjects that exist in all world religions, like morality, to the session and discuss their messages to all of humanity. With such practices, a certain religion or sect is prevented from being dominant. Another type of intervention is religious music or hymns. Participation in worship activities and rituals is a form of intervention; however, participants are not forced to participate in these activities. The positive effects of the program are learned from the adolescents themselves, who said that they had experienced no prejudice and that they were neither ostracized nor felt to be excluded. They further stated they were not judged by their past and that the program's practitioners were interested in the here and now. They appreciated the fact that they were being listened to, understood, and that their needs were being fulfilled. In this program, participants pray for each other, find relief for their problems, and do not feel alone. Participants interested in religion or who develop an interest in religious through the program say that their beliefs increased by reading the Bible and that God is present in every moment of life (Branch, 2002).

Each spiritual dimension has been adapted to a 20 -session psychological counseling program for delinquent adolescents who use narcotic substances. One of the conditions of participation is that the individual has used alcohol, any number of stimulants, cocaine, or opium derivative drugs in the last 30 days. The spiritual dimensions used in the sessions are meditation, prayer, celebration, acceptance, thankfulness, fasting, 
serving others, worship, retreats, deep thinking exercises, self-care, peace, and guidance. These dimensions also constitute the content of the sessions. These dimensions are approached on the basis of spiritual counseling. Psychological counseling begins with a pre-interview. A total of 20 sessions are planned over the course of four months. However, it is a sign of success if the client states that he no longer needs counseling beginning on the 12th week. Follow-up sessions are held 4, 8, and 12 months following the first meeting. In this psychological counseling program, a detailed explanation is provided for how to use each spiritual dimension effectively (Miller, 2004):

Table 3

Miller's Spiritual Counseling Program, Developed for Adolescents Who Use Drugs

\begin{tabular}{|c|c|c|}
\hline Field & Usage in Psychological Counseling & Important Spiritual Techniques \\
\hline Meditation & $\begin{array}{l}\text { Meditation for adolescents who use narcotic } \\
\text { substances entails praying and sing for } \\
\text { transcendence in silence and awareness. } \\
\text { Conditions necessary for meditation are a quiet } \\
\text { environment, a focus point, and the meditator's } \\
\text { being relaxed and attentive so that he is able } \\
\text { to listen to his inner voice. A single meditation } \\
\text { session can last } 5,10 \text {, or } 15 \text { minutes. The client } \\
\text { is expected to transferring these practices into his } \\
\text { daily routine. }\end{array}$ & $\begin{array}{l}\text { The person invited to meditate feels } \\
\text { the transcendent power in the inner } \\
\text { space. In meditation, images are } \\
\text { also used. The most commonly used } \\
\text { images are white light, Jesus Christ, } \\
\text { and crosses. }\end{array}$ \\
\hline Praying & $\begin{array}{l}\text { Through prayer, one aims to communicate } \\
\text { and be together with the Divine. Clients find } \\
\text { prayer meaningful and useful. Acceptance and } \\
\text { Commitment Therapy is used during prayer. }\end{array}$ & $\begin{array}{l}\text { Worship: To express one's love and } \\
\text { praise to God. } \\
\text { Confession: To confess one's } \\
\text { deficiencies. } \\
\text { Giving thanks: Showing gratitude to } \\
\text { God for the blessings He has given. } \\
\text { Supplication: Beseeching God to } \\
\text { fulfill one's own wishes and those of } \\
\text { others. }\end{array}$ \\
\hline Fasting & $\begin{array}{l}\text { Fasting is a sacred act of worship practiced by } \\
\text { Jews, Christians, Muslims, and Hindus. Juvenile } \\
\text { delinquents fast to gain self-control and to become } \\
\text { more aware of their values and thoughts. }\end{array}$ & $\begin{array}{l}\text { In order to fast, approval is sought } \\
\text { from a qualified health personnel. } \\
\text { The person cannot fast for more than } \\
24 \text { hours. Only the person fasting } \\
\text { knows that he is fasting and does not } \\
\text { tell others. }\end{array}$ \\
\hline Self Care & $\begin{array}{l}\text { Western (i.e., Abrahamic) religions say that paying } \\
\text { attention to the body and physical health is a } \\
\text { form of worshipping God. Meeting these needs is } \\
\text { necessary for well-being. }\end{array}$ & $\begin{array}{l}\text { Maslow's hierarchy of needs can be } \\
\text { used as it focuses on what the client's } \\
\text { needs are and what makes him happy } \\
\text { in life. }\end{array}$ \\
\hline Deep Thinking & $\begin{array}{l}\text { Deep thinking is to focus on an object or } \\
\text { experience. These objects and experiences can be } \\
\text { holy books, sacred texts, music, and nature. }\end{array}$ & $\begin{array}{l}\text { Keeping a diary is a technique that } \\
\text { can be used to focus on spiritual } \\
\text { experiences. }\end{array}$ \\
\hline Seclusion & $\begin{array}{l}\text { Becoming distant from everyday routines to be } \\
\text { alone with God is supported by most religions. A } \\
\text { client practicing seclusion is in search of truth and } \\
\text { meaning. }\end{array}$ & $\begin{array}{l}\text { The client may want to have a } \\
\text { certain time of the day without } \\
\text { television and telephone. During } \\
\text { these periods, the client may be asked } \\
\text { to focus on meditation, prayer, and } \\
\text { contemplation. The client can be } \\
\text { asked to spend a weekend or a day } \\
\text { in nature. }\end{array}$ \\
\hline
\end{tabular}


Table 3

Miller's Spiritual Counseling Program, Developed for Adolescents Who Use Drugs

\begin{tabular}{|c|c|c|}
\hline Field & Usage in Psychological Counseling & Important Spiritual Techniques \\
\hline Acceptance & $\begin{array}{l}\text { Acceptance is to accept oneself and all of one's } \\
\text { characteristics. Also within let it go meditation, } \\
\text { the person removes his limitative thoughts from } \\
\text { his mind. Acceptance allows the client to accept } \\
\text { others as they are and to open places for them. } \\
\text { It is the spiritual dimension that brings spiritual } \\
\text { discipline. }\end{array}$ & $\begin{array}{l}\text { Appreciation of power, letting go } \\
\text { of one's thoughts, submission, and } \\
\text { belief are reflected upon and studied. }\end{array}$ \\
\hline Serving & $\begin{array}{l}\text { This is the act of helping society and other people. } \\
\text { The client learns to serve with loyalty, solidarity, } \\
\text { and compassion, which can help him to increase } \\
\text { spirituality, reduce bad behaviors, and overcome } \\
\text { substance addiction. }\end{array}$ & $\begin{array}{l}\text { The client may seek voluntary work } \\
\text { for the benefit of society and help his } \\
\text { parents with household chores more } \\
\text { frequently. }\end{array}$ \\
\hline Peace & $\begin{array}{l}\text { Forgiveness and confession include aspects related } \\
\text { to peacefulness. The client is thus in a peaceful } \\
\text { state with others and himself. }\end{array}$ & $\begin{array}{l}\text { When the dimension of peacefulness } \\
\text { is studied, not only are the client's } \\
\text { religious breakpoints researched but } \\
\text { also where, when and under what } \\
\text { conditions the client's relationships } \\
\text { with other individuals and with God } \\
\text { occurred. }\end{array}$ \\
\hline 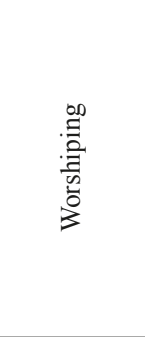 & $\begin{array}{l}\text { Worship is the appreciation and praise of the } \\
\text { greatness of God. Although worship is seen as a } \\
\text { social issue, the desired situation is for worship to } \\
\text { be completed privately. }\end{array}$ & $\begin{array}{l}\text { The client's previous worship } \\
\text { experiences are discussed during } \\
\text { counseling. The client is asked } \\
\text { to continue worshipping alone } \\
\text { or communally and to give an } \\
\text { evaluation of his worship. In addition } \\
\text { to learning to see worship as both an } \\
\text { internal and external spiritual journey } \\
\text { during counseling, the client studies } \\
\text { community service. }\end{array}$ \\
\hline 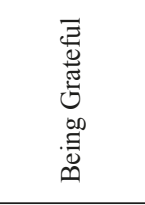 & $\begin{array}{l}\text { Being grateful is seen as an antidote for the } \\
\text { client's selfish ambitions and behaviors as well as } \\
\text { for his materialist views. The client looks at her } \\
\text { heart for good things and spends time to find them. }\end{array}$ & $\begin{array}{l}\text { It is not correct practice to allow only } \\
5 \text { minutes for being grateful during } \\
\text { counseling sessions. Instead it is to } \\
\text { be practiced in such a way that it } \\
\text { becomes a part of the client's daily } \\
\text { life. }\end{array}$ \\
\hline 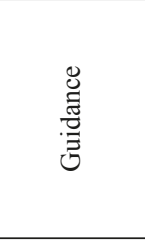 & $\begin{array}{l}\text { Through reading biographies, autobiographies, } \\
\text { and writings of historical personalities, the client } \\
\text { is guided in his spiritual development. The Prophet } \\
\text { Muhammed (saws), Jesus Crist (sa), Buddha, the } \\
\text { Dalai Lama Martin Luther King, and Mahatma } \\
\text { Gandhi can be seen as spiritual guides. The aim is } \\
\text { for the client to access his internal voice. }\end{array}$ & $\begin{array}{l}\text { In addition to historical and religious } \\
\text { role models, support groups such } \\
\text { as Anonymous Alcoholics, priests, } \\
\text { imams, pastoral counselors, and } \\
\text { religious leaders may be spiritual } \\
\text { guides. }\end{array}$ \\
\hline : & $\begin{array}{l}\text { Celebrating constitutes looking at the positive side } \\
\text { of life. Energy can be expended on the beautiful } \\
\text { aspects of life, instead of exerting energy on } \\
\text { feeling anxious, nervous, anxious, and resentful. }\end{array}$ & $\begin{array}{l}\text { During spiritual counseling, } \\
\text { celebrations can be organized for an } \\
\text { adolescent client who has given up } \\
\text { using a narcotic substance. }\end{array}$ \\
\hline
\end{tabular}

\section{Spiritual Interventions in Prison for Delinquent Children}

Spiritually oriented psychological counseling practices and faith-based interventions have been made for children who have been driven to crime and who therefore reside 
in prison. The purpose of faith-based interventions is to character conversion through religious practices and spiritual harmony. The implication of character conversion is to study the perceptions of justice with these children and to facilitate them to reinterpret their perceptions of justice so as to prevent possible damage that may arise in society (Zehr, 2002). These programs are called reparative faith-based interventions because they include a reinterpretation of clients' perceptions of justices and entail recovery from harm. Reparative faith-based interventions provide the development or strengthening of spiritual emotions. Children are motivated to be good people. The program's practitioners are good role models for children and the program seeks to prevent children from performing behaviors with negative consequences. Children participating in this prevention study feel guilty when they behave in a way that do not conform with their spirituality. In other words, as a result of the program, spirituality takes on a cognitive aspect in the child, allowing prosocial behaviors develop (Tangney, Stuewig, \& Mashek, 2007). In addition, empathy is studied emotionally. Through empathy, a connection between feeling guilt and behaving less aggressively is sought to be established. The behaviors arising with the connection include self-devotion and self-motivation. The delinquent child tries to repair relationships using self-devotion and motivation after feeling remorse and empathy (Sandage, Worthington, Hight, \& Berry, 2000).

After identifying faith-based intervention programs and defining their limits, information about the sessions of the program are to be given in the following section. During counseling sessions, interventions are made to explain the effects of clients' behaviors, to help them gain self-confidence, and to help them be at peace with God and others. Clients are placed into groups consisting of 10 individuals and are asked to read the book Restoring Peace: Using Lessons from Prison to Mend Broken Relationships by Blackard and Sage. Volunteers working with children include lawyers of victims, psychological counselors, and church officials. Volunteers are trained before working with children and work with two similar groups. The first session is an orientation where clients receive a copy of the book and a program guide. Clients follow a single course from the second to thirteenth session. Before each session, the clients read a related chapter from the Bible and the book. Topics of discussion for the weekly session may include such themes as responsibility, regret, and repentance. Each session begins with a video related to the topic followed by a question and discussion section. After the discussion section, the clients are divided into small groups where they share their experiences about this topic. They then write these experiences and conclusions. From the second session to the fifth session, the subject pertains to clients' expectations and concerns about the program, crime and conflict, and finding spirituality and power in each other's stories. The subsequent eight sessions include spiritual content. In the sixth session, clients study the crimes they have committed, their perceptions of the law, and their responsibilities. The 
seventh session is about accountability and includes content related to self-esteem and the ability to make choices. The eighth session is confession and change. During this session, clients profess to themselves and to God their regret for the people that they have hurt. The ninth session during which clients turn to God for a spiritual and ethical change focuses on repentance. In the tenth session, God's forgiveness and forgiving oneself and others are studies. During this session the positive psychological effects of being forgiven are also discussed. The eleventh session is about being at peace with God, oneself, his family and other people. During the twelfth session, restitution and compensating for the effects of crime are studied. In the thirteenth session, clients travel spiritually to their pasts using what they have learned during the program. During the final session, clients bid farewell to each other and to the practitioner, who states his own views about the program and the process. In other words, the final session is a graduation session for the clients where they receive their graduation certificates and testimonials (Armour, Windsor, Aguilar, \& Taub, 2008).

\section{Spiritual Interventions in Schools for Delinquent Children and Their Family}

Spiritual counseling in school is seen as a resource that can be used for delinquent children. The reason that spiritual counseling has entered into school practices is due to spirituality's supportive nature in the development of adolescents and children. Spirituality can be integrated into school counseling so that children's optimal functioning may increase, and development continue (Dobmeier, 2011; Ruddock \& Cameron, 2010). School counselors can use the spiritual and religious aspects of the students as development, preventive, and remedial intervention resources (Richards, Bartz, \& O'grady, 2009).

Problem areas in which spirituality can be used as a remedial resource in school counseling are mentioned in the literature. Spirituality can be used as a resource during interventions for loss and mourning, developing perseverance and persistence, increasing hope, teaching coping skills, preventing students from becoming pregnant and dropping out, teaching how to cope with the effects of divorce (Sink \& Richmond, 2004), crime prevention, addiction to narcotic substances, alcohol, and cigarettes, and improving academic success (Colgan, 2001). In addition, school counselors should recognize that spirituality is a way of expressing one's own life while evaluating students. School counselors should be aware that students may express their spiritual behaviors through jewelry, accessories, tattoos, the kinds of music they listen to, and prayer. In addition, the school psychological counselor should respect students' social structure, experiences, beliefs, and motivation processes (Sink, 2004). In counseling, the psychological counselor can plan activities about the cognitive, emotional, social, moral, and spiritual aspects of the problems brought by students. Areas for improvement in the spiritual intervention approach include compassion, well-being, kinship, searching for meaning, and developing confidence and integrity. 
Through these areas, school psychological counselors work to prevent the existing problem from being exasperated (Dobmeier, 2011). When the school counselor uses spirituality as a resource in these problem areas, their therapeutic responsibilities are having a non-judgmental attitude, being open to students, and being supportive while students discuss their feelings and thoughts (Rayburn, 2004). The school counselor tries to stay neutral while discussing spiritual issues, taking care that his own values do not affect the child. Furthermore, school counselors are to pay attention to the impression they have on students and how students react to spiritual debates (Wolf, 2004).

After explaining the meaning of spiritual counseling in schools, discussing the limits of spiritual counseling, an identifying possible problem areas and roles of a psychological counselor, $d$ it is necessary to examine the techniques that a counselor can use. Drama, role-playing, reading spiritual resources, discussing case studies, and practicing effective listening skills are among the spiritual techniques that a psychological counselor may use. In addition, the integrated use of spiritual subjects with Reality Therapy, Choice Theory, and Humanistic Psychological Counseling Theory can increase positive results. These theories share the centrality of the need for love and belonging, putting values foreground in life, valuing the person, and the Sacred Common sides increase the power of integration (Wolf, 2004).

Spirituality can also be worked on developmentally in school counseling. Spiritual development counseling is conducted by studying three interrelated areas, i.e., as part of cognitive, emotional, and moral development, since spiritual development affects the progress of children in these developmental areas (Benson, 2004). The other is the beginning of abstract and logical thinking with puberty. By way of logical thinking, adolescents begin to evaluate their personality through their own eyes, express their emotions, create their own personal truths, and form their identity, these areas can also be worked on spiritually (MacDonald, 2004). Adolescent identity formation can be undertaken on its own using spirituality. The adolescent's spiritual interests are learned for identity-personality formation and the adolescent is provided supported in line with his spiritual interests. For clients who refuse spiritual development, their healthy development is sought to be maintained. It appears that those areas where spirituality is lacking are also likely to have unrealized developmental tasks and can be developed through spiritual-based activities (Benson \& Roehlkepartain, 2008).

The structure of a spiritual counseling session in schools focusing on these problem areas is composed of an introduction, spiritual and religious intervention, and discussion. Information concerning privacy, obtaining participants' consent, and determining the topic to be discussed in the following session are issues that belong to the first session. During spiritual and religious interventions, the similarities and 
differences between spirituality and religion are discussed. Being a part of something bigger than oneself, searching for meaning, creating goals, motivation sources can be worked on using spirituality and religion as a medium. of the concepts of transcendence and the boundaries of space, time, and matter may be items of discussion on the agenda. Furthermore, yoga, meditation, walking, keeping a diary, and reading may also be used as intervention methods and are considered secular interventions techniques (Ruddock \& Cameron, 2010). Discussed during the evaluation stage are how such issues as transcendence, awareness of the Sacred's power, meaning, motivation, and life force have manifested in the client and whether the client has experienced a change in his religious and spiritual state and understanding. The session is ended by soliciting comments and questions from clients (Wolf, 2004). An intervention implemented in this way may be applied in school spiritual interventions as planning interventions during psychological counseling sessions in this way may also be useful for delinquent children.

Spiritual interventions seen in the related literature for juvenile delinquents in which educational staff and families are involved may be regarded as faith-based interventions as well. Such three-legged models aim are to protect the child from risk, to prevent recidivism, to provide peer support, to improve academic achievement, to organize family relationships, and to prevent the child form using and becoming addicted to alcohol cigarettes, or other substances. These programs are also called faith-based protection programs, since the main goals are to increase school engagement, attendance and academic success, and to eliminate risk factors (Barry, Sutherland, \& Harris, 2006). Faith-based protection programs can be conducted by such organizations as churches, synagogues, and mosques. The programs are mostly conducted with children of families who have financial disadvantages. While providing academic support to and being role models for children, the family is provided with secular family counseling and family education services (Gehring, 2004). For this reason, the Table 4 describes the religious organization, family, and school cooperation style (Epstein, Simon, Salinas \& Voorhis, 2002):

Similarly, faith-based training programs were produced to protect truant children from committing crime. The goals of this ten-month program are to ensure continued attendance to school, to prevent dropouts, to preclude criminal behavior in children, to help children establish positive friendships, to teach planning skills, and to strengthen religious and spiritual aspects. At the same time, life skills are sought to be imparted in children through this program. Training takes place in the organizing establishment. Those involved in this program are teachers, trainers, pastoral counselors, psychological counselors, and social workers. Participants are divided into six to eight groups and a program is conducted for each group. Children from outside and who are not at risk can also participate in such programs. Service hours are flexible, and can take place on 
Table 4

Collaboration between Religious Organizations, Family and Schools

Cooperation Style Interventions

Parents may be trained in parenting skills, family support, understanding adolescence and child development, and how to foster a supportive home

Parenthood environment for children of all ages. In schools, training can be arranged in order to explain the social and cultural structure of the family as well as aims for their children.

Families are informed about the school's educational plans and their children's

Communication progress. Establishing a communication channel between the family and the school is also sought.

Families can participate in activities organized by religious organizations both

Volunteering as participants and observers in and out of school. Volunteers who support the school and the students may cooperate with the school and the family.

Education and counseling services are given to parents regarding how they may academically support their children at home. They are asked to help their

Teaching at Home children with homework. and to support their children in creating academic goals. By communicating with their teachers, they may be asked to work and give homework on topics that attract their child's interest.

The families of these children can participate in decision-making workshops,

Making Decisions $\quad$ school-run family organizations, and developmental teams composed of parents and children.

It is possible to establish links between families in need of a job and NGOs,

Cooperation with Society cultural and civic organizations, companies, and agencies. Religious institutions can meditate in this regard.

weekdays, evenings, and weekends. Mathematics, English, science, and social sciences courses are provided to children by teachers. Traing in computers, software, art, music, drama, entrepreneurship, and life skills is given by trainers. In addition to learning student and family responsibilities, participants also learn how to communicate with the young, the elderly and persons with disabilities. Children can spend time watching television, using game consoles and computers, and playing basketball and table tennis. Children also participate in spiritual and religious education, such as church activities, Bible lessons, and going on retreats in addition to a film evening, basketball tournament, dance activities (Sinha, 2007).

Religion is also a concept that can be examined in the context of school counseling. It has been reported that having religious beliefs and participating in religious groups leads to lower levels of depression, lower suicide rates, less substance use, fewer problem behaviors, less crime, and more positive social behaviors (Davis, Kerr, \& Kurpius, 2003). For this reason, psychological counselors working in schools should know religious orientation and values of the student when performing any form of evaluation, counseling, consultation, or intervention (Halstead, 2005). According to the religious and spiritual demographic diversity of the school, school psychological counselors can plan activities for students in an effort to support this diversity (La Torre, 2002). If school psychologists do not ask questions related to the spirituality and religious beliefs of their students, they may have difficulty establishing therapeutic relationships with them. The reason for this difficulty is that a child 
might feel that he is not understood and that his religious and/or spiritual values are not considered valuable enough to discuss. For this reason, school psychological counselors can use religious and spiritual resources to understand these children's psychological development and to work with their psychological problems (Burke et al., 1999). In addition, school counselors can use spiritual and religious knowledge to build collaboration between the school and families. For example, if a delinquent child comes from a religious minority group, the school psychological counselor may contact the child's family to understand what the special needs of the child are and to work toward having these needs satisfied by the school. Since some families do not want their children to work with someone of different religious beliefs than their own, school counselors can also intervene by taking advantage of their own religious background and provide explanations for parents' concerns and questions related to their children's behaviors and developments. In addition, the religious and spiritual perspectives of families can provide empathy and a stronger therapeutic relationship between school psychological counselors and delinquent children of the same religion backgrounds. If psychological counselors consider these factors, the resistance exhibited by families may decrease (Bass, 2011).

\section{Conclusion}

In the Turkish literature on this subject, there are books describing the theories of spiritual psychology, including the definition and limitations of spiritual psychology. At the same time, there are quantitative studies in which spirituality is taken as a variable and there are qualitative studies examining how spirituality is perceived by people belonging to various groups. Yet, there no study has been conducted examining juvenile delinquency from the viewpoint of spiritual psychology. For this reason, this study may be a guide to psychological counselors and social workers interested in this issue. On this basis, the spirituality of such children can be studied in qualitative and quantitative researches. The deterrent effect of spirituality in preventing recidivism, the religious and spiritual experiences of these children, and their perspectives of religiosity and spirituality can be qualitatively studied. It is important to recognize these children and their spirituality and to interpret juvenile delinquency from the point of view of Turkish culture. However, developing multicultural spiritual counseling sessions for juvenile delinquency may contribute to the field. 


\section{References}

Agnew, R. (2006). Pressured into crime: An overview of general strain theory. Los Angeles, CA: Roxbury Publishing Company.

Allen, T. M., \& Lo, C. C. (2010). Religiosity, spirituality, and substance abuse. Journal of Drug Issues, 40(2), 433-459.

Armour, M. P., Windsor, L. C., Aguilar, J., \& Taub, C. (2008). A pilot study of a faith-based restorative justice intervention for Christian and non-Christian offenders. Journal of Psychology and Christianity, 27(2), 159-167.

Barry, A. E., Sutherland, M. S., \& Harris, G. J. (2006). Faith-based prevention model: A rural African-American case study. American Journal of Health Studies, 21(3), 148-157.

Bartol, A. M., \& Bartol, C. R. (2014). Criminal behavior: A psychological approach. Boston, MA: Pearson.

Bass, J. M. (2011). Religion, spirituality, and school psychology: A national survey of training programs. Educational Specialist, 34, 1-58.

Benson, P. L. (2004). Emerging themes in research on adolescent spiritual and religious development. Applied Developmental Science, 8(1), 47-50.

Benson, P., \& Roehlkepartain, E. (2008). Spiritual development: A missing priority in youth development. New Directions for Youth Development, 118, 13-28.

Branch, A. Y. (2002). Faith and action: Implementation of the national faith-based initiative for high-risk youth. Philadelphia, PA: Public/Private Ventures.

Burke, M. T., Hackney, H., Hudson, P., Miranti, J., Watts, G. A., \& Epp, L. (1999). Spirituality, religion, and CACREP curriculum standards. Journal of Counseling \& Development, 77, 251-257.

Bülbül, S., \& Doğan, S. (2016). Suça sürüklenen çocukların durumu ve çözüm önerileri [Current situation of the children driven to crime and solution proposals.]. Çocuk Săgllğı ve Hastalıkları Dergisi, 59, 31-36.

Chui, W. H., Cheng, K. K. Y., \& Wong, L. P. (2013). Spirituality and punitiveness: An exploration of Christian, Buddhist, and non-religious attitudes towards crime. International Journal of Law, Crime and Justice, 41(1), 1-15.

Cochran, J., Wood, P., \& Arneklev, B. (1994). Is the religiosity-delinquency relationship spurious a test of arousal and social-control theories. Journal of Research in Crime and Delinquency, 31, 92-123.

Cohen, S. (2004). Social relationships and health. American Psychologists, 59(8), 676-684.

Colgan, C. (2001). In good faith. Principal Leadership, 2(1), 10-15.

Coşar, Y. (2005). Kentleşen Türkiye'de çocuk suçluluğu [Juvenile delinquency in urbanizing Turkey]. Türkiye Barolar Birliği Dergisi, 56, 281-327.

Çocuk Koruma Kanunu. (2005). 5395 Sayılı Kanun. 03.07.2005.

Davis, T. L., Kerr B. A., \& Kurpius, S. E. (2003). Meaning, purpose, and religiosity in at risk youth: The relationship between anxiety and spirituality. Journal of Psychology and Theology, 31, 356-365.

Dobmeier, R. (2011). School counselors support student spirituality through developmental assets, character education, and ASCA competency indicators. Professional School Counseling, 14(5), 317-327.

Ennew, J. (2003). Sokak çocukları ve çalışan çocuklar: Planlanma için bir rehber, gelişim el $k i t a b l$ [Street and working children- A guide to planning]. Ankara, Turkey: UNICEF Türkiye Temsilciliği Yayınları. 
Epstein, J., Simon, B. S., Salinas, N. R., \& Voorhis, F. L. (2002). School, family, and community partnerships: Your handbook for action. Thousand Oaks, CA: Corwin Press.

Gehring, J. (2004). Philadelphia schools reach out to faith groups. Education Week, 24(11), 3-15.

Güngör, M. (2008). Evrensel bir sorun olarak çocuk suçluluğu ve sokakta çalışan ve yaşayan çocuklar [Juvenile delinquency as universal problem and children working and living outdoors]. Adlyaman Üniversitesi Sosyal Bilimler Enstitüsü Dergisi, 1, 25-43.

Herrenkohl, T. I., Hill, K. G., Chung, I. J., Guo, J., Abbott, R. D., \& Hawkins, J. D. (2003). Protective factors against serious violent behavior in adolescence: A prospective study of aggressive children. Social Work Research, 27(3), 179-191.

Halstead, J. M. (2005). Religion, culture, and schooling. In C. L. Frisby \& C. R. Reynolds (Eds.), Comprehensive handbook of multicultural school psychology (pp. 394-424). Hoboken, NJ: John Wiley.

Johnson, B. R., \& Jang, S. J. (2011). Crime and religion: Assessing the role of the faith factor. In R. Rosenfelld, K. Quinet, \& C. Garcia (Eds.), Contemporary ussues in criminological theory and research (pp. 117-149). Hampshire, Uk: Wadsword Cangage Learning.

Köknel, E. (2017). Gençlik suçları [Youth offenses]. Retrieved from https://www.kriminoloji.com/ Genclik_Suclari-KOKNEL.htm

La Torre, M. A. (2002). Spirituality and psychotherapy: An important combination. Perspectives in Psychiatric Care, 38(3), 108-110.

MacDonald, D. (2004). Collaborating with students' spirituality. Professional School Counseling, 7(5), 293-300.

Miller, W. R. (1999). Integrating spirituality into treatment: Resources for practitioners. Washington, DC: American Psychological Association.

Miller, W. R. (2004). Spiritual evocation: Guidelines for spiritual direction in drug abuse treatment (Unpublished treatment manual). University of New Mexico Center on Alcoholism, Substance Abuse and Addictions (CASAA), Albuquerque. Retrieved from https://casaa.unm.edu/ download/Spiritual\%20Evocation.pdf

Mirowsky, J., \& Ross, C. (2003). Social causes of psychological distress. New York, NY: Aldine de Gruyter.

Neff, J. A., Shorkey, C. T., \& Windsor, L. C. (2006). Contrasting faith-based and traditional substance abuse treatment programs. Journal of Substance Abuse Treatment, 30(1), 49-61.

Pargament, K. I. (2002). The bitter and the sweet: An evaluation of the costs and benefits of religiousness. Psychological Inquiry, 13, 168-181.

Pargament, K. I., \& Saunders, S. M. (2007). Introduction to the special issue on spirituality and psychotherapy. Journal of Clinical Psychology, 63(10), 903-907.

Pearce, L. D., \& Haynie, D. L. (2001). Dimensions of religion in families and adolescent delinquency: Examining the role of religious incongruities. Anaheim, CA: American Sociological Association.

Powell, K. B. (1997). Correlates of violent and nonviolent behavior among vulnerable inner-city youths. Family \& Community Health, 20(2), 38-47.

Pulla, V. (2014). Spiritually sensitive social spiritually sensitive social work: The roadworth taking. In B. R Nikku \& Z. A Hatta (Eds.), Social work education and practice: Scholarship and ınnovations in the Asia Pacific (pp. 194-211). London, UK: Primrose Hall Publishing Group. 
Rayburn, C. (2004). Assessing students for morality education: A new role for school counselors. Professional School Counseling, 7(5), 356-352.

Regnerus, M. D. (2003). Linked lives, faith, and behavior: Intergenerational religious influence on adolescent delinquency. Journal for the Scientific Study of Religion, 42(2), 189-203.

Richards, S., Bartz, J., \& O'Grady, K. (2009). Assessing religion and spirituality in counseling: Some reflections and recommendations. Counseling and Values, 54, 65-79.

Ruddock, B., \& Cameron, R. (2010). Spirituality in children and young people: A suitable topic for educational and child psychologists. Educational Psychology in Practice, 26(1), 25-34.

Salas Wright, C. P., Vaughn, M. G., Hodge, D. R., \& Perron, B. E. (2012). Religiosity profiles of American youth in relation to substance use, violence, and delinquency. Journal of Youth and Adolescence, 41(12), 1560-1575.

Salas Wright, C. P., Olate, R., \& Vaughn, M. G. (2013). The protective effects of religious coping and spirituality on delinquency: Results among high-risk and gang-involved Salvadoran youth. Criminal Justice and Behavior, 40(9), 988-1008.

Salas-Wright, C. P., Vaughn, M. G., \& Maynard, B. R. (2014). Religiosity and violence a mong adolescents in the United States: Findings from the national survey on drug use and health 2006-2010. Journal of Interpersonal Violence, 29(7), 1178-1200.

Sandage, S. J., Worthington, E. L., Jr., Hight, T. L., \& Berry, J. W. (2000). Seeking forgiveness: Theoretical context and an initial empirical study. Journal of Psychology and Theology, 2(1), 21-35.

Sider, R. J., \& Unruh, H. R. (1999). No aid to religion? Charitable choice and the first amendment. Brookings Review, 17, 46-49.

Simpson, D. D. (2004). A conceptual framework for drug treatment process and outcomes. Journal of Substance Abuse Treatment, 27, 99-121.

Singh, A., \& Bhadra, S. (2014). Life skills education (LSE) for juvenile delinquent: Developing a behaviour health promotional model. Artha Journal of Social Sciences, 13, 21-32.

Singh, A., \& Bhadra, S. (2017). Mental health promotion for juvenile delinquents: strengthening spiritual wellness through life skills education (LSE) interventions. Partringe Publishing.

Sinha, J. W. (2007). Youth at risk for truancy detour into a faith-based education program: Their perceptions of the program and its impact. Research on Social Work Practice, 17(2), 246-257.

Sink, C. (2004). Spirituality and comprehensive school counseling programs. Professional School Counseling, 7(5), 309-315.

Sink, C., \& Richard, L. (2004). Introducing spirituality to professional school counseling. Professional School Counseling, 7(5), 291-292.

Shoemaker, D.J. (2008). Juvenile delinquency. Maryland: Rowman \& Littlefield Publishers.

Summermatter, A., \& Kaya, Ç. (2017). An overview of spiritually oriented cognitive behavioral therapy. Spiritual Psychology and Counseling, 2(1), 31-53.

Topçuoğlu, T. (2014). Çocuk suçluluğu ve gelişimsel (risk-odaklı) suç önleme [Juvenile crime and developmental (risk-focused) crime prevention]. Karamanoğlu Mehmetbey Üniversitesi Sosyal ve Ekonomik Araştırmalar Dergisi, 16(1), 217-226.

U.S. Department of Justice. (2011). Faith-based corrections and reentry programs: Advancing a conceptual framework for research and evaluation (2007-IJ-CX-0019). Washington, DC: Urban Institute Justice Policy Center. 
Waaijman, K. (2007). What is spirituality? Acta Theologica, 27(2), 1-18.

Wahl, R. A., Cotton, S., \& Monore, P. H. (2008). Spirituality, adolescent suicide, and the juvenile justice system. The Southern Medical Association Journal, 204, 711-715.

Wolf, J. (2004). Teach, but don't preach: Practical guidelines for addressing spirituality concerns of students. Professional School Counseling, 7(5), 363-366.

Yoshikawa, H. (1995). Long-term effects of early childhood programs on social outcomes and delinquency. The Future of Children, 5, 51-75.

Zehr, H. (2002). The little book of restorative justice. Intercourse, PA: Good Books. 